\title{
FEATURES OF VALUE ASSESSMENT SCIENTIFIC-INDUSTRIAL COMPLEX
}

\author{
T.A. Fedorova ${ }^{1}$, A.Y. Gorbachev ${ }^{2}$ \\ ${ }^{1}$ Doctor of Economic Sciences, Associate Professor, Rector, Komi Republican Academy of State Services \\ and Management, Russia, Komi Republic, Syktyvkar, 167982, Kommunisticheskaya str., 11, \\ tatiana75@mail.ru \\ ${ }^{2}$ Chief of the Sector of Pricing, Central Design Office Machine Construction, Russia, Tula, Demonstration \\ str., 36, merc123@ mail.ru
}

\begin{abstract}
The market and macroeconomic trends and the demand for knowledge-intensive products urge on interest of investors in producers of innovations. In Russia today the most effective structure on creation and release of innovative production are scientific and production complexes. Their task includes carrying out applied research and developmental works, release of prototypes and rendering support to the industrial enterprises for the organization of serial release of the innovative products developed by them. Thus, the innovative activity of industrial enterprises and their investment activity largely depend on the results of research and production complexes. Therefore it is necessary to form effective mechanisms of management of these structures. The purpose of the study is to develop an approach to the valuation of the scientific and production complex, taking into account the peculiarities inherent in its activities. The cost of the research and production complex is one of its characteristics, reflecting the status and effectiveness of its work. Methods of valuation of research and production complex should adequately take into account its actual financial and economic situation. The article describes the existing methodological approaches to the valuation of innovative active enterprises. Features of activity of the scientific and production complex including existence of possibility of parallel implementation of two processes are analyzed: receiving the income from the current activity and carrying out research and developmental works, release of prototypes, that is implementation of innovative projects with "remote" financial results. As a result of the research, a new approach to assessing the value of the research and production complex, adequate to the economic processes of its activities, the use of which in the formation of the investment portfolio of the enterprise contributes to the capital of the enterprise.
\end{abstract}

Keywords: scientific-industrial complex, cost, assessment, innovations, investments

\section{INTRODUCTION}

Efficiency rate of development of modern economy depends on volumes of use of innovative products. Developed countries of the world (the USA, China, Japan, Russia) annually increase budgetary appropriations by researches and product developments of civil appointment. So in 2016 they respectively make: in the USA - 62,7 billion a dale., in China - 59,1 billion a dale., in Japan - 33,1 billion a dale., in Russia - 18,5 billion a dale ${ }^{1}$.

On increase in efficiency of the Russian industry directionally the State program "Development of the industry and increase in its competitiveness" developed by the Government of the Russian Federation which provides a number of measures for development of the international cooperation and export, and also necessary for this

\footnotetext{
${ }^{1}$ Investing in science: towards a knowledge economy. Proposals of the Russian Academy of Sciences to improve the efficiency of investments in the development of basic research and exploratory research // Presidium of the Russian Academy of Sciences. Moscow. 2016. 44 p.
}

Submit Date: 09.01.2018, Acceptance Date: 23.02.2018, DOI NO: 10.7456/1080MSE/138

Research Article - This article was checked by Turnitin

Copyright (C) The Turkish Online Journal of Design, Art and Communication 
action for the purpose of increase in competitiveness of the knowledge-intensive products and creation of conditions for the direction of investments into the innovative sector of economy ${ }^{2}$.

The considerable volumes of transactions concluded in the field of export and import of technologies between Russia and other countries are confirmed statistical data and demonstrate activation of international trade in technologies from Russia ${ }^{3}$. So, export volume on total number of agreements in spheres of a know-how, patents, using innovations and scientific research in Russia for the period made 2016 registration of trademarks, industrial services $8991,6 \mathrm{mln}$. dollars of the USA, and export - 7 724,6 mln. dollars of the USA. The greatest number of transactions consists in the field of engineering and scientific research (export - $7516,5 \mathrm{mln}$. dollars of the USA, import - $4617,5 \mathrm{mln}$. dollars of the USA), owing to natural tendencies of search of methods of implementation of works with lower costs.

Availability of notable state support and growth of activity of participants of the market of the knowledgeintensive products accumulates interest of different investors, representatives of the banking sector, the companies and holdings in the enterprises implementors of innovative activity ${ }^{4}$.

In Russia one of the most effective structures performing innovative activity are the scientific-industrial complexes (further - SIC) which kept scientific and technical potential since the former USSR and accumulated experience of use of the new opportunities which opened in connection with universal use of information technologies 5 .

One of integral characteristics of activity of SIC in market economy is its market value. Value of level of market value of SIC allows to carry out comparative efficiency evaluation of work of the enterprise, to estimate the real situation of the enterprise in the market and its financial state that ${ }^{6}$, in turn, allows the enterprise to create an adequate investment strategy.

Approaches and methods to value assessment of innovatively active enterprises are considered in publications of many authors from which especially it is necessary to distinguish S. V. Valdaytsev, A. Damodaran, T. Copeland, T. Koller, J. Murrin. However highly risk and multidimensional organization activities, engaged in research and development, demands a research of features of their activity and their accounting at assessment of market value of such organizations.

\section{Purpose, tasks}

The purpose of the conducted research is development of approach to value assessment of the scientificindustrial complex considering the features inherent in its activity.

For achievement of this purpose the following tasks were set:

- to investigate the scheme of forming of the capital of innovatively active enterprise;

- to analyze the existing approaches to value assessment of innovatively active enterprise;

\footnotetext{
${ }^{2}$ Resolution No. 382-13 of 31 March 2017. In accordance with the Budget code, the parameters for financing the state programme have been brought into line with the Federal law on the Federal budget for 2017 and the 2018 and 2019 planning period. The number of subprogrammes has been reduced from 21 to eight.[website] http://government.ru/docs/27128/

${ }^{3}$ Russian statistical yearbook. 2017: Stat.SB. // Rosstat. P76 M. 2017. 728 p.

${ }^{4}$ Acemoglu D. Localized and Biased Technologies: Atkinson and Stiglitz's new view, Induced Innovations, and Directed Technological Change // The Economic Journal, 2015. Vol. 125. P. 443 - 463.

${ }^{5}$ Yegerev I. A. the value of the business: Art of management : textbook. the manual. M.: Case. 2003. 480 p.

${ }^{6}$ Maurizio Pompella, Antonio Dicanio. RatingsbasedInferenceandCredit Risk: Detecting likely-to-fail Banks with the PC-Mahalanobis Method // Economic Modeling. 2017. V. 67, December, p. 34-44. [site.] URL: https://www.sciencedirect.com/science/article/pii/S026499931630270X
} 
- to analyze features of activity of scientific-industrial complex as the enterprise performing creation of innovative products by means of carrying out applied research, developmental and production works;

- to develop the scheme of formation of the capital of SIC;

- to develop approach to value assessment of SIC;

- to formulate recommendations about practical use of the received results.

\section{MATERIALS AND METHODS}

SIC - the enterprise performing creation of innovative products by means of carrying out applied research, developmental and production works ${ }^{7}$. SIC for maintenance of the competitiveness needs to analyze results of development of fundamental science, and also results of the activity, timely to consider reaction of final consumers to products and to react timely to change of trends of the market and state of the economy. Being in the general trend, and it is even better, advancing it, creating new market niches for the knowledge-intensive products, SIC creates the capital ${ }^{89}$.

The following model of forming of its capital is characteristic of innovatively active industrial enterprise ${ }^{10}$.

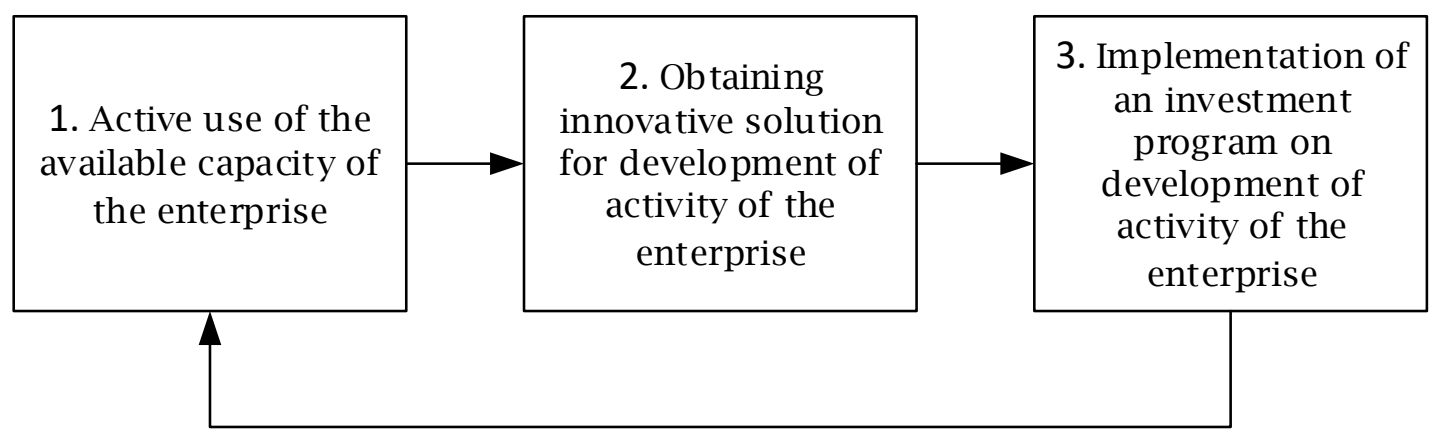

\section{Illustration 1. Scheme of formation of the capital of the enterprise}

Innovatively active enterprise performs production, using the material and non-material resources which are available for it ${ }^{11}$. Availability of the steady product demand of the enterprise and acceptable profit level, the performed activity received from, creates conditions for making decision on implementation of the innovative project $^{12}$. The profit on implementation of such project can be got both in the current planning period, and in remote perspective that demands implementation of performance appraisal at each stage of work on this project and if the result is positive, then such project can be approved to execution. On the basis of the concept of

\footnotetext{
${ }^{7}$ Fedorova E. A., Gorbachev Yu capacity-building research and production complex // UGUID Bulletin. V. 79. 2017. No. 2. P. $337-345$.

${ }^{8}$ Mohammed Anwar Hillawi Garbawi. The main mechanisms for managing the capitalization of the company // Modern Economy Success. 2017. № 5. P. 54 - 57.

${ }^{9}$ Maurizio Pompella, Antonio Dicanio. Ratings based Inference and Credit Risk: Detecting likely-to-fail Banks with the PC-Mahalanobis Method // Economic modeling. 2017. V. 67. December. P. 34 - 44. [site.] URL: https://www.sciencedirect.com/science/article/pii/S026499931630270X

${ }^{10}$ The formation of the cost of innovation-active enterprises: monograph / T. A. Fedorova. Tula: "Lidar-Art". 2010.175 p.

${ }^{11}$ Scott R. Baker, Nicholas Bloom And Steven J. Davis. Measuring Economic Policy Uncertainty // The Quarterly Journal of Economics. 2016. Vol. 131. P. 1593 - 1636.

${ }^{12}$ Valdaytsev S.V. business Valuation and cost management of the enterprise. Moscow: UNITY. 2003. 720 p.
} Submit Date: 09.01.2018, Acceptance Date: 23.02.2018, DOI NO: 10.7456/1080MSE/138

Research Article - This article was checked by Turnitin

Copyright (C) The Turkish Online Journal of Design, Art and Communication 
development of activity of the enterprise created thus the investment project forms ${ }^{13}$. The received results allow the enterprise to use again updated potential for further implementation of activity.

Cycling repetition of processes in this case is directed to value addition of innovatively active enterprise, by means of implementation in activity of new methods of production of urgent products ${ }^{14}$.

It should be noted that the capacity of the enterprise is understood as the greatest possible amount of works which can execute the enterprise according to the available resources ${ }^{15}$.

For cost determination of innovatively active enterprise the following two-phase mode ${ }^{16}$ can be used:

$$
V=\sum_{t=1}^{n} \frac{C F_{t}}{(1+W A C C)^{t}}+\frac{C F_{n+1} /\left(W A C C_{s t}-g_{s t}\right)}{(1+W A C C)^{n}}
$$

where $\mathrm{V}$ - size of cost of the enterprise;

$C F_{t}$ - value of size of a cash flow in timepoint $\mathrm{t}$;

$t$ - sequence number of year of work of the enterprise, since assessment moment;

$1 \leq \mathrm{t} \leq \mathrm{n}-$ period of growth of the enterprise high rates;

$\mathrm{n}+1$ - sequence number of year since which the enterprise grows at stable rates;

WACC, WACC $_{\text {st }}$ - weighted average capital cost in the period of bystry and stable demand of growth respectively;

$\mathrm{g}_{\mathrm{st}}-$ growth rates of operating profit in the period of stable growth.

The provided formula (1) allows to make value assessment of the enterprise by means of the analysis of two essentially differing periods in development of the enterprise:

- the rapid growth provided with earlier received innovative solution on development of activity of the enterprise and the investments involved to implementation;

- the period of stable growth on the basis of the stabilized growth rates when the available capacity of the enterprise is used for stable profit earning.

However activity of SIC differs from the considered model of formation of the capital provided in the figure 1 .

\footnotetext{
${ }^{13}$ Kerr W., Lerner J., Stern S. Innovation Policy and the Economy // University of Chicago Press Journals. 2015. P. 102 -110 .

${ }^{14}$ Copeland T., Koller T., Murrin J. Valuation: measuring and managing the value of companies // McKinsey \& company, Inc., John Willey \& Sons, Inc. 1999. 576 p.

${ }^{15}$ Fedorova E. A., Gorbachev Yu capacity-building research and production complex. // UGUID Bulletin. V. 79.2017. No. 2. P. $337-345$.

${ }^{16}$ Damodaran A. Investment valuation. Tools and techniques of assessment of any asset; lane. from English. Moscow: Alpina Business Buks. 2004. 1342 p.
} 
Planning of activity of SIC is performed by means of collecting of the work requests submitted in the form of orders ${ }^{17}$. Sources of forming of requests are:

- third parties, such, as: enterprises, organizations, research institutions, government institutions, venture funds and other;

- the initiative developments of SIC based on own analysis of the enterprise of requirements of the market and a possibility of their satisfaction with determination of a financing source.

Production of SIC is performed within the applied research works performed by it which can be provided by one or several thematic directions ${ }^{18}$.

Also important circumstance is that SIC potential, as a rule, allows to implement at the same time several orders at the same time. The realization of orders is enabled by means of use of its resources to which carry ${ }^{19}$ :

- the engineering procedures representing technical and technology solutions which logical chain allows to perform release of innovative products;

- the personnel of the corresponding number and qualification which are carrying out works;

- the equipment and the machine base including required type of rooms for the placement and allowing to carry out works;

- financial resources as the volume of the means demanded for work by request.

The SIC resources are distributed in the enterprise between divisions.

For more evident representation the described scheme of the organization of activity of SIC it is representable the formula (2) characterizing accounting treatment for resources of the enterprise.

$$
R_{j}=\sum_{k=1}^{m} R_{j k},
$$

where $R_{j}$ - total volume of $j$-th resource of SIC.

$\mathrm{j}$ - type of the considered resource $(\mathrm{j}=1 \div \mathrm{n})$;

$\mathrm{k}$ - thematic direction $(\mathrm{k}=1 \div \mathrm{m})$.

Besides, for the analysis of activity of SIC it is necessary to consider types of the orders realized by it from the point of view of their functional influence on a possibility of a change in value of the enterprise.

Generally orders are implemented for the purpose of profit earning by the enterprise by means of use of the resources which are available for it. However orders are different on duration of the execution. A number of works can be implemented by SIC in a year, and others in three or five years. Therefore the first property in

\footnotetext{
${ }^{17}$ Fedorova E. A., Gorbachev, Y. A. Evaluation of the order when planning the programme of activities of scientificindustrial complex. Corporate governance and innovative development of the North's economy // Bulletin of the research center of corporate law, management and venture investment of Syktyvkar state University. 2017. № 4. P. 13 - 19.

${ }^{18}$ Yong Zhang Modeling and dynamic assessment on sustainable development of drainage enterprise: Application of a coupled system dynamics - comprehensive assessment model // Journal of Cleaner Production. 2017. Volume 141. January 10. P. $157-167$.

${ }^{19}$ Fedorova E. A., Gorbachev Yu capacity-building research and production complex // UGUID Bulletin. V. 79.2017. No. 2. P. $337-345$.
} 
the analysis of the order from the point of view of capital rating of SIC is "remoteness" of obtaining financial result. If terms of order fulfillment are longer, than the period during which assessment of the enterprise is performed, then similar works can be carried to investments with remote result.

The remote result of program implementation can be considered as result from investing activities as investments of costs in such projects allow to accumulate the asset cost of the enterprise ${ }^{2021}$.

The second factor is influence of the order for the SIC resources. In this case it is necessary to consider the possibility of "change" of the SIC resource, the possibility of change of final cost of the enterprise is a consequence of what. It is necessary to understand opportunities as "changes" of the SIC resources on:

- to increase or reduction of volume of the resource which is available for the enterprise;

- modernizations of a resource;

- to introduction of a new resource.

Implementation of the orders "changing" the SIC resources is performed for the purpose of a possibility for the enterprise to perform more profitable and urgent works afterwards, and also maintenance of quality of the performed processes at the competitive level according to tendencies of development of the market and scientific and technical progress.

However in the activity also it agrees to the potential which is available for SIC, the enterprise implements at the same time a number of the orders allowing to get profit in the period of assessment ${ }^{22}$, and also the orders allowing to gain effect in the future, that is orders with "remote" financial result. At the same time the potential of SIC is at the same time distributed between a possibility of accomplishment of the orders providing stable income level and orders allowing to provide the demand rapid growth period.

\section{RESULTS}

On the basis of stated, 1 scheme of formation of the capital of innovatively active enterprise considered in the drawing, for a case of SIC it is possible to provide according to the figure 2 .

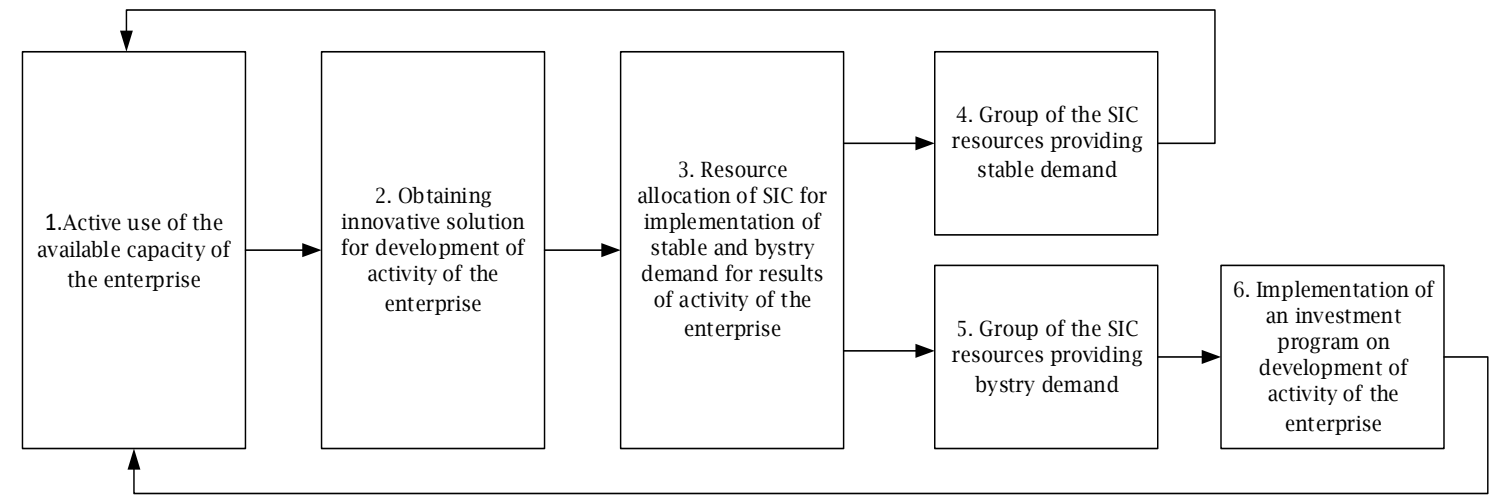

\footnotetext{
${ }^{20}$ John H. Reappraising the Eclectic Paradigm in an Age of Alliance Capitalism // The Eclectic Paradigm. 2015. P. 111 $-142$.

21 Aihua Huang, Fazleena Badurdeen. Sustainable Manufacturing Performance Evaluation: Integrating Product and Process Metrics for Systems Level Assessmen. // Procedia Manufacturing-2017. V. 8. P. 563 - 570.

${ }^{22}$ Mina Moeinedini A Fuzzy Fault Tree Analysis based Risk Assessment Approach for Enterprise Resource Planning Projects: a Case Study in an Iranian Foodservice Distributor // International Journal of Quality Science merged into international Journal of Quality \& Reliability Management. 2018. [site.] URL: https://www.emeraldinsight.com/doi/abs/10.1108/IJQRM-03-2016-0037
} 


\section{Illustration 2. Scheme of formation of the capital SIC}

In activities of SIC for building of the capital it is necessary to allocate resources for forming of the stable demand relating to the current activity and quickly growing demand for results of innovative activity of the enterprise in remote perspective. The last group of resources creates an investment program on development of activity of the enterprise.

At the same time a formula (1) it is provided possible to rewrite according to the new factors inherent for SIC:

$$
V=\sum_{t=1}^{n} \frac{C F_{t}^{S t}}{\left(1+W A C C^{S t}\right)^{t}}+\sum_{t=1}^{n} \frac{C F_{t}^{I n v}}{\left(1+W A C C^{I n v}\right)^{t}}+V_{t e r m}
$$

where $V$ - size of cost of the SIC;

$C F_{t}^{S t}$ - value of size of a cash flow from implementation of the orders allowing to get profit in timepoint of $\mathrm{t}$;

$C F_{t}^{I n v}$ - value of size of a cash flow in timepoint of $\mathrm{t}$ from implementation of investment programs;

$t$-sequence number of year of work of the enterprise, since assessment moment, $t=\overline{1, n}$;

$n$ - valuation horizon, advanced in years;

$W A C C^{I n v}$ - the weighted average cost of the SIC resources used in programs with "remote" financial result;

$W A C C^{S t}$ - the weighted average cost of the SIC resources used at implementation of the orders making profit in a current period of time of $\mathrm{t}$;

$V_{\text {term }}{ }^{-}$the thermal cost determined by Gordon's formula:

$$
V_{\text {term }}=\frac{C F_{n+1} /\left(W A C C^{s t}-g_{s t}\right)}{\left(1+W A C C^{s t}\right)^{n}}
$$

The weighted average cost of the SIC resources used in the current activity and investment programs can be both identical, and excellent depending on the policy of attraction of resources used by the enterprise for accomplishment of investment projects (as a rule, higher in connection with higher risks of investment projects in comparison with the current activity of the enterprise).

The formula (3) reflects the offered approach to value assessment of SIC allocating three cost elements in structure of its cost: value assessment, generating the current cash flows; value assessment from generation of cash flows after implementation of investment projects; the thermal cost as the completing assessment element.

\section{DISCUSSION}

SIC as well as any other company develops, augmenting the capital. Different approaches to value assessment of SIC are possible. For example, within an income approach it is necessary to estimate the size of the cash flows generated by $\mathrm{SIC}^{23}$. At comparative approach it is required to define objects, similar for assessment, and for costly - to estimate the cost of separate elements of property of SIC. However features of SIC as the economic unit, first, which is engaged within the activity including in projects with "remote" financial return, secondly, often being unique that complicates their comparison to other objects, thirdly, having rather small

\footnotetext{
${ }^{23}$ Bykovskaya E.V. the Essence and role of the strategic approach in the management system of an industrial enterprise // Modern Economy Success. 2017. № 4. P. 79 - 82.
} 
costs, but the high market potential of the developed products, demand the corrected approach to value assessment of SIC.

The main feature in work of SIC is connected with simultaneous accomplishment of orders which bring in incomes in a current period, and researches which can become orders in the future and respectively bring in the income in the future, and now belonging to investments. Therefore the methods developed for assessment of innovatively active enterprises more are suitable for value assessment of SIC. However, as showed a research, the existing evaluation method of market value of innovatively active enterprise ${ }^{24}$, it is developed for the newly created enterprise with allocation of the period of rapid growth when new developments of innovatively active enterprise enter the market and win the positions, and with a subsequent period of stable growth when products of the new company become these products recognized the market ${ }^{2526}$, the market it is saturated, and growth rates are stabilized ${ }^{27}$.

In this regard SIC developed in approach for the purposes of assessment, has to be corrected. SIC is the operating plant which already passed the rapid growth period. However its activity assumes emergence of such periods in the future when demand for new products becomes "bystry", and growth rates of SIC exceed stable again. In other words, SIC is the enterprise with the repeating rapid growth periods. Therefore the corrected formula of value assessment of SIC was offered.

The considered approach allows the management of SIC and to potential investors to make reasoned decisions when forming a package of orders on innovative projects on the basis of value assessment of SIC.

Also becomes possible to make the analysis of dynamics of activity of the enterprise, by means of comparison of tasks of the organization of activity of SIC to the implemented methods of their achievement in different periods and on the basis of the obtained data to create the strategy of long-term development. In turn, the purpose of similar strategy is establishment of a vector of development of activity of SIC as the main element of competitiveness allowing to implement the urgent thematic directions of works by means of forming by the enterprise of required types and volumes of resources.

\section{CONCLUSIONS}

Results of the conducted research show that the cost of SIC forms by means of use of the following two groups of resources of the enterprise:

- groups of the resources providing stable demand by means of release of small-scale lots of products of the enterprise;

- groups of the resources providing bystry demand, by means of implementation of innovative projects with "remote" financial result and being means for the enterprise for material accumulation.

\footnotetext{
${ }^{24}$ Fedorova T. A. The formation of the cost of innovation-active enterprises: monograph. Tula: "Lidar-Art". 2010.175 p.

${ }_{25}$ Prokhorov O.V. problems of introduction of technological innovations in commercial enterprises of the Russian Federation and possible ways of their solution // International scientific and practical Symposium of young scientists and specialists Economic policy of modern Russia, St. Petersburg. Publ IMTS NWS-SPb. 2013. 289 p.

${ }^{26}$ Mina Moeinedini A Fuzzy Fault Tree Analysis based Risk Assessment Approach for Enterprise Resource Planning Projects: a Case Study in an Iranian Foodservice Distributor // International Journal of Quality Science merged into international Journal of Quality \& Reliability Management. 2018. [site.] URL: https://www.emeraldinsight.com/doi/abs/10.1108/IJQRM-03-2016-0037

${ }^{27}$ A. Pyka, J. Foster (eds.). The Evolution of Economic and Innovation Systems, Economic Complexity and Evolution, DOI 10.1007/978-3-319-13299-0_2 // Reprinted from Journal of Evolutionary Economics, Springer. 2014.24 (2). P. 1 39.
} 
It should be noted that two provided groups of resources in the amount form SIC capital value. Therefore results of activity of SIC in many respects depend on capability of the management of the enterprise to distribute the available resources of the enterprise between implementation of two project groups.

Overall performance of SIC is reached at compensation by the cash inflows which are available in a current period from implementable orders of outflows of investment projects SIC, monetary, necessary for implementation, with "remote" financial result.

The possibility of parallel implementation of processes of SIC on project implementation with stable and bystry demand is reached by means of:

- the availability corresponding at the enterprise of volumes of resources;

- established practices of methods of the organization of activity of the enterprises of this kind.

Forming of the investment portfolio and accomplishment of investment projects creates the capital of SIC necessary for the next periods of its development. Objective assessment of growth of the capital of SIC is assessment of its cost. On the other hand, value assessment of SIC is necessary for the analysis of results of activity of the enterprise, with the subsequent forming of an investment strategy of development.

The conducted research allowed to prove new approach to value assessment of the scientific-industrial complex considering the features inherent in its activity.

It is established that in relation to SIC the scheme of forming of the capital of innovatively active enterprise and the existing approaches to value assessment of innovatively active enterprise demand the adjustments reflecting features of activity of SIC.

Features of activity of scientific-industrial complex as the enterprise performing creation of innovative products by means of carrying out applied research, developmental and production works, consisting in simultaneous accomplishment of orders, revenue-producing in a current period, and researches and developments with "remote" financial result are revealed.

The scheme of formation of the capital of SIC considering availability at SIC of two groups of the resources providing the current stable demand and bystry demand with "remote" financial result is developed.

The revealed features of activity of SIC demanded entering of the corresponding adjustments into value assessment of SIC as innovatively active enterprise, on the one hand, and operating plant with the repeating rapid growth periods, on the other hand.

The approach to value assessment of SIC allocating three cost elements in structure of its cost is reasonable: value assessment, generating the current cash flows; value assessment from generation of cash flows after implementation of investment projects; the thermal cost as the completing assessment element.

Recommendations about practical use of the received results are formulated. The offered approach to value assessment of SIC reflecting economic processes of its activity gives adequate value assessment to SIC and allows creating such investment portfolio of the enterprise which promotes growth of the capital of the enterprise.

\section{REFRENCES}

Investing in science: towards a knowledge economy. Proposals of the Russian Academy of Sciences to improve the efficiency of investments in the development of basic research and exploratory research // Presidium of the Russian Academy of Sciences. Moscow. 2016. 44 p. 
The Turkish Online Journal of Design, Art and Communication - TOJDAC

ISSN: 2146-5193, March 2018 Special Edition, p. 317-327

Resolution No. 382-13 of 31 March 2017. In accordance with the Budget code, the parameters for financing the state programme have been brought into line with the Federal law on the Federal budget for 2017 and the 2018 and 2019 planning period. The number of subprogrammes has been reduced from 21 to eight.[website] http://government.ru/docs/27128/

Russian statistical yearbook. 2017: Stat.SB. // Rosstat. P76 M. 2017. 728 p.

Acemoglu D. Localized and Biased Technologies: Atkinson and Stiglitz's new view, Induced Innovations, and Directed Technological Change // The Economic Journal, 2015. Vol. 125. P. 443 - 463.

Yegerev I. A. the value of the business: Art of management : textbook. the manual. M.: Case. 2003. 480 p.

Maurizio Pompella, Antonio Dicanio. RatingsbasedInferenceandCredit Risk: Detecting likely-to-fail Banks with the PC-Mahalanobis Method // Economic Modeling. 2017. V. 67, December, p. 34-44. [site.] URL: https://www.sciencedirect.com/science/article/pii/S026499931630270X

Fedorova E. A., Gorbachev Yu capacity-building research and production complex // UGUID Bulletin. V. 79. 2017. No. 2. P. $337-345$.

Mohammed Anwar Hillawi Garbawi. The main mechanisms for managing the capitalization of the company // Modern Economy Success. 2017. № 5. P. $54-57$.

Maurizio Pompella, Antonio Dicanio. Ratings based Inference and Credit Risk: Detecting likely-to-fail Banks with the PC-Mahalanobis Method // Economic modeling. 2017. V. 67. December. P. 34 - 44. [site.] URL: https://www.sciencedirect.com/science/article/pii/S026499931630270X

The formation of the cost of innovation-active enterprises: monograph / T. A. Fedorova. Tula: "Lidar-Art". 2010. $175 \mathrm{p}$.

Scott R. Baker, Nicholas Bloom And Steven J. Davis. Measuring Economic Policy Uncertainty // The Quarterly Journal of Economics. 2016. Vol. 131. P. 1593 - 1636.

Valdaytsev S.V. business Valuation and cost management of the enterprise. Moscow: UNITY. 2003.720 p.

Kerr W., Lerner J., Stern S. Innovation Policy and the Economy // University of Chicago Press Journals. 2015. P. $102-110$.

Copeland T., Koller T., Murrin J. Valuation: measuring and managing the value of companies // McKinsey \& company, Inc., John Willey \& Sons, Inc. 1999. 576 p.

Fedorova E. A., Gorbachev Yu capacity-building research and production complex. // UGUID Bulletin. V. 79. 2017. No. 2. P. $337-345$.

Damodaran A. Investment valuation. Tools and techniques of assessment of any asset; lane. from English. Moscow: Alpina Business Buks. 2004. 1342 p.

Fedorova E. A., Gorbachev, Y. A. Evaluation of the order when planning the programme of activities of scientific-industrial complex. Corporate governance and innovative development of the North's economy // Bulletin of the research center of corporate law, management and venture investment of Syktyvkar state University. 2017. № 4. P. $13-19$.

Yong Zhang Modeling and dynamic assessment on sustainable development of drainage enterprise: Application of a coupled system dynamics - comprehensive assessment model // Journal of Cleaner Production. 2017. Volume 141. January 10. P. 157 - 167.

Fedorova E. A., Gorbachev Yu capacity-building research and production complex // UGUID Bulletin. V. 79. 2017. No. 2. P. $337-345$.

John H. Reappraising the Eclectic Paradigm in an Age of Alliance Capitalism // The Eclectic Paradigm. 2015. P. $111-142$.

Aihua Huang, Fazleena Badurdeen. Sustainable Manufacturing Performance Evaluation: Integrating Product and Process Metrics for Systems Level Assessmen. // Procedia Manufacturing-2017. V. 8. P. 563 - 570.

Mina Moeinedini A Fuzzy Fault Tree Analysis based Risk Assessment Approach for Enterprise Resource Planning Projects: a Case Study in an Iranian Foodservice Distributor // International Journal of Quality Science merged into international Journal of Quality \& Reliability Management. 2018. [site.] URL: https://www.emeraldinsight.com/doi/abs/10.1108/IJQRM-03-2016-0037

Bykovskaya E.V. the Essence and role of the strategic approach in the management system of an industrial enterprise // Modern Economy Success. 2017. № 4. P. $79-82$.

Fedorova T. A. The formation of the cost of innovation-active enterprises: monograph. Tula: "Lidar-Art". 2010. $175 \mathrm{p}$. 
Prokhorov O.V. problems of introduction of technological innovations in commercial enterprises of the Russian Federation and possible ways of their solution // International scientific and practical Symposium of young scientists and specialists Economic policy of modern Russia, St. Petersburg. Publ IMTS NWS-SPb. 2013. $289 p$.

Mina Moeinedini A Fuzzy Fault Tree Analysis based Risk Assessment Approach for Enterprise Resource Planning Projects: a Case Study in an Iranian Foodservice Distributor // International Journal of Quality Science merged into international Journal of Quality \& Reliability Management. 2018. [site.] URL: https://www.emeraldinsight.com/doi/abs/10.1108/IJQRM-03-2016-0037

A. Pyka, J. Foster (eds.). The Evolution of Economic and Innovation Systems, Economic Complexity and Evolution, DOI 10.1007/978-3-319-13299-0_2 // Reprinted from Journal of Evolutionary Economics, Springer. 2014. 24 (2). P. $1-39$. 